\title{
KONSEP TEOLOGI DAN HUMANISME DALAM FILSAFAT CINA
}

\author{
Muhammad Taufik \\ Kementerian Agama Provinsi Daerah Istimewa Yogyakarta \\ E-Mail: muhammadtaufikmandailing@yahoo.com \\ Diterima 07 Desember 2010/Disetujui 23 Januari 2011
}

\begin{abstract}
Abstrak
Filsafat Cina tidak cenderung terlalu ekstrim menekankan pemikiran filsaafat "ke luar" maupun "ke dalam". Filsafat Cina lebih menekankan keseimbangan di antara keduanya. Dalam konsep humanisme pemikiran filsafat Cina mempunyai corak tersendiri bila dibandingkan dengan humanisme yang dianut di Barat dan pada umumnya. Humanisme dalam tradisi Cina tidak ada pengingkaran pada Yang Maha Agungyang menunjukkan adanya unifikasi dengan antara manusia sebagai Makbluk dan Tuhan sebagai Khalik.
\end{abstract}

Kata kunci: teologi, humanisme, filsafat Cina, tradisi Cina

\section{Pendahuluan}

Cina merupakan bangsa besar dan mempunyai peradaban berumur ratusan tahun, yang hingga kini masih kuat berpegang pada tradisi yang telah dibuat oleh leluhur mereka. Di samping kebesaran peradabannya, Cina juga menempati ranking pertama penduduk terbesar di dunia, serta mempunyai wilayah yang sangat luas. Dalam tradisi mereka itu tercakup berbagai pemikiran tentang Tuhan dan manusia dan hubungan yang terjadi antara keduanya.

Filsafat Cina tidak cenderung terlalu ekstrim menekankan pemikiran filsaafat "ke luar" maupun "ke dalam". Filsafat Cina lebih menekankan keseimbangan di antara keduanya. Masalah ketuhanan tidak termasuk menjadi masalah utama, walaupun sebenarnya Konfuciusme dan Taoisme ada menyinggungnya, namun tidak secara sistematis dan metodologis. Tapi sebaliknya masalah kemanusiaan termasuk menjadi perhatian utama. Sungguhpun demikian akan memunculkan pertanyaan-pertanyaan 
bagaimana sebenarnya konsep teologis dan humanisme dalam alam filsafat Cina.

Selama ini, memang sedikit penulis yang mencoba mengeksplorasi tentang masalah ketuhanan dan manusia dalam kultur bangsa Cina, sebab banyak penulis lebih concern pada Barat dan Islam (walau ini juga termasuk dalam kajian Timur), sehingga pembahasan tentang Cina hanya mendapat porsi yang sedikit. Oleh karena itu penulis mencoba menguak "Tirai Bambu" pemikiran tentang bagaimana konsep teologi dan humanisme dalam pemikiran filsafat Cina.

\section{Konsep Teologi dalam Tradisi Cina}

"Berkata rasul-rasul mereka: "Apakah ada keragu-raguan terhadap Allah, Pencipta langit dan bumi..” (Q.S. 14.10)

Di atas adalah dalil qur'ani dalam Islam tentang hipotesa tentang Tuhan. Tuhan (sesudah kita membatasi arti perkataan itu) ada atau tidak ada. Walaupun kepercayaan kepada Tuhan itu terdapat dalam beberapa agama, dan walaupun agama Yahudi, Kristen, dan Islam merupakan agamaagama yang monoteistik (tauhid), tetapi ada agama-agama seperti agama Budha yang tidak mengandung kepercayaan tentang Tuhan. Oleh karena itu sangat penting sekali kita menyelidiki problem tentang adanya Tuhan. ${ }^{2}$

Sebagaimana bangsa-bangsa lain di dunia, bangsa Cina juga mempunyai rumusan tentang teologi yang mengatur hubungan mereka dengan tuhan dan sesama mereka. Dalam kehidupan yang dijalani oleh bangsa Cina mereka ada mengenal "Thien" (Surga) dan "Shang-ti" (Tuhan Yang Maha Tinggi) sebagai yang mempunyai kuasa Tertinggi yang a personal. Ia merupakan suatu keteraturan universal yang meresapi seluruh realitas. Kekuasaan tersebut bersifat baik dan bijaksana, Ia memerintah seluruh alam semesta dengan sangat adilnya. Mereka percaya bahwa proses

${ }^{1}$ Lihat al-Qur'an al Karim Departemen Agama RI

${ }^{2}$ David Trueblood, Filsafat Agama, terjemahan H.M. Rasyidi, Jakarta: Bulan Bintang, 1990), h. 40.

${ }^{3}$ Shang-ti artinya sama dengan Kaisar di Atas, yaitu Tuhan dalam pengertian modern. Artinya Tuhan dapat danggap serupa dengan raja di dunia. Lihat, Nio Joe Lan, Tiongkok Sepanjang Abad, (Jakarta: Balai Pustaka, 1952), h. 37. 
awal alam ini diciptakan berawal dari penciptaan Tuhan pada dua hal: "Nafas dan Kekuatan", kedua kekuatan inilah yang kemudian menjadikan segala sesuatu yang terbentang di alam semesta ini. Kekuatan pertama terang seperti cahaya, panas, dapat bergerak dan bersifat hidup, ia disebut dengan Yang. Kekuatan kedua gelap, dingin, berwujud benda padat dan tak bergerak, dan disebut dengan Yin. ${ }^{4}$

Dalam kosmologi Cina, puncak segala sesuatu sebelum ada Yin dan Yang adalah Tai Chi (Puncak Yang Agung), yang kemudian melahirkan unsur Yin dan Yang dalam kehidupan. Yin dan Yang dipahami sebagai prinsipprinsip eksistensi yang bersifat aktif dan reseptif. Yin dan Yang merangkul satu sama lain dalam suatu keselarasan dan keterpaduan. Keduanya menghasilkan banyak hal, yaitu segala sesuatu yang ada. Simbol Tai Chi dan Tao, melukiskan Yin dan Yang sebagai gerakan dan perubahan yang konstan. Yin dan Yang adalah prinsip-prinsip perubahan dan simbol bagi seluruh gerakan di alam semesta.

Daya cipta sifat Tuhan yang memberi gerak dan hidup kepada sesuatu, itulah Yang, sedangkan Yin adalah zat yang diberi kemampuan bergerak dan hidup itu. Yang bersifat memberi dan memperbanyak, Yin memperbanyak dan menyimpan. Dari Yin dan Yang terbentuklah air, bumi, kayu, logam dan api. Dari kelima bahan itu dijadikanlah dunia ini dan semua makhluk yang hidup di dalamnya. Yin dan Yang keduanya tunduk pada hukum alam, sehingga dalam gerak geriknya nampak ada suatu aturan dan rbytme (irama) yang meliputi dan mengisi setiap ruang dalam alam raya ini, seperti perputaran bumi, bulan, matahari, perubahan musim dan lainnya.

Ritme ini dalam pemikiran filsafat Cina dinamakan dengan "Tao", yaitu "jalan", jalan bagaimana segala sesuatu di dunia ini dijadikan, dan jalan bagaimana orang mengatur hidupnya. Sebab bila ia mengerti “jalan” itu maka ia akan selamat dan bahagia karena mendapat berkah dari Tuhan. Sebaliknya bila orang tidak menurut pada "jalan" tersebut maka akan banyak mendapat kesukaran dan kesengsaraan dalam hidupnya. ${ }^{5}$ Menurut

${ }^{4}$ Elizabeth Seeger, Sejarah Tiongkok Selayang Pandang, terj. Ong Pok Kiat dan Sudarno, (Jakarta: J.B. Wolters-Groningen, 1951), h. 49-50.

${ }^{5}$ Elizabeth Seeger, Sejarah Tiongkok......h. 50-51. 
Lao-tse 6 " Tao tidak dapat dilihat, didengar, bahkan tidak dapat disebut. Alangkah tenangnya Tao ini. Ia tidak berbentuk, tapi ada di mana-mana. Semua yang ada di dunia ini tergantung pada Tao untuk dapat hidup. Ia mencintai semua makhluk dan memberi makan semuanya dan tidak berharap dibalas budinya, semua berasal dari Tao dan kembali kepadanya. Ia terkecil dari yang kecil dan yang terbesar dari yang terbesar. Demikian Lao-Tze menggambarkan Tuhan yang disebutnya dengan Tao tersebut.

Filasafat Taoisme mengajar orang supaya menerima nasib, baik suka dan duka, bahagia dan bencana sama saja dalam pandangan Taoisme. Oleh karena itu seorang penganut Taoisme dapat memikul suatu penderitaan dengan hati yang tegar seberat apapun cobaan tersebut. ${ }^{7}$ Hal ini dasarkan pada keyakinan dan kepercayaannya pada "Tao" sebagai jalan Tuhan.

Supaya orang dapat menyelaraskan hidupnya dengan dengan Jalan Tuhan, maka menurut Taoisme, setiap manusia dilahirkan dalam keadaan suci dan baik. Dari Tuhan, ia mendapat sifat yang membimbing ke arah kebaikan, yaitu ramah, sopan, cerdas, jujur, dan hormat. Kelima sifat baik ini harus ada pada manusia, maka ia akan salah kalau tidak menggunakan sifat tersebut, tapi bila ia menggunakannya maka akan bisa menjaga hubungan dengan sesama manusia dan juga alam. ${ }^{8}$

Berbeda dengan Taoisme tentang konsep Tuhan, bagi Konfucius ${ }^{9}$ Tuhan bukan berbentuk manusia. Tuhan jarang dipahami secara demikin di zamannya dan menolak gagasan yang berkaitan dengan hal itu. Jika dipahami cara konfucius memahami Tuhan tampak dalam pandangannya, istilah ini menggambarkan suatu kekuatan moral dalam alam semesta yang dipahami secara samar-samar. Ia memberikan pengutamaan yang sebesar-

${ }^{6}$ Lao-tse seorang pemikir Cina terkemuka di zamannya dan sangat dikenal hingga sekarang ini. Ia hidup sezaman dengan Kung-Tze atau di dunia Barat dikenal dengan Konfucius. Lao-Tze lahir tahun 571 S.M. di Ku-hsien, nama aslinya adalah Li Erl, sedangkan Lao-Tze berarti pujangga Lao. Ia berasal dari suatu keluarga yang terhormat dan menjadi penjaga arsip kaisar. Lihat, Nio- Joe Lan, Tiongkok......h. 48.

${ }^{7}$ Ibid., h. 49.

${ }^{8}$ Elizabeth Seeger, Sejarah Tiongkok......, 51.

${ }^{9} \mathrm{Nama}$ Konfucius di kenal di Barat sedangkan dalam bahasa Cina Kung Fu-tse. Ia dilahirkan di daerah Lu, di Shantung pada tahun 551 S.M. Ia merupakan seorang filosof besar di daratan Cina. Ibid., h. 100. Banyak yang beranggapan bahwa Konfucius adalah pendiri sebuah agama, padahal itu tidak benar, yang benar adalah pemikirannya menjadi aliran filsafat yang menjadi panutan yang sangat banyak di Cina. 
besarnya pada ikhtiar manusia, dan Tuhan sekiranya hanya menolong. Karena ia melihat orang yang jahat hidupnya makmur sedangkan orang yang baik justru sengsara. Meskipun demikian konsep mengenai Tuhan memberinya perasaan bagaimana ada suatu kekuasaan yang berdiri di pihak mereka yang kesepian yang memperjuangkan kebenaran ${ }^{10}$ Barangkali dalam konteks inilah Nietzsche ${ }^{11}$ seorang filosof Jerman mengatakan bahwa Tuhan itu telah mati (Got is tot). Ia mengatakan demikian, karena ia melihat bahwa Tuhan tidak memperlihatkan kekuasaan atau perannya ketika ada penindasan pada yang lemah oleh yang berkuasa, sedangkan Tuhan tidak berbuat apa-apa. Akhirnya ia hal tersebut membuat ia skeptis terhadap keberadaan dan peran Tuhan.

Ada suatu catatan penting tentang ciri khas Cina, bahwa ia tidak memunculkan konsep yang jelas tentang relasi antara manusia dan Tuhan, namun hanya relasi antara manusia sesama manusia. Konsep teologinya begitu samar dan tidak transparan dan amat lemah kadarnya, dan kemudian akan diperdalam oleh Budhisme. Tidak dapat dipungkiri bahwa filsafatnya lebih banyak berbicara tentang kebaikan, keindahan, dan kebenaran.

Dewasa ini, Konfucianisme memiliki fungsi dan kedudukan ganda, antara lain sebagai filsafat, maupun agama. Sebagai sebuah sistem filsafat, maka Konfucianisme menekankan bidang etika sebagai aturan tingkah laku dan pedoman umum bagi para penganutnya, sehingga sering dikatakan bahwa Konfucianism adalah sistem filsafat yang humanistik. Sementara sebagai budaya, Konfucianisme dapat ditelaah melalui perkembangan ajarannya yang hampir mewarnai sebagian besar budaya Cina, yang kemudian diwujudkan dalam adat istiadat, kebiasaan, ritual, maupun sebagai pedoman hidup sehari-hari. ${ }^{12}$

Konfucianisme dan Taoisme adalah dua aliran besar dalam pemikiran dan agama Cina. Akan tetapi janganlah kita bayangkan bahwa kedua tradisi itu telah menghabiskan waktu lebih dari dua ribu tahun dalam bersaing satu sama lain. Keduanya mempunyai pengaruh penting dalam pemikiran

${ }^{10}$ H.G. Creel, Alam Pikiran Cina, Sejak Konfucius sampai Mao Zedong, terj. Soejono Sumargono, (Yogyakarta: Tiara Wacana, 1990), h. 38.

${ }^{11}$ Lihat St. Sunardi, Niettesche, (Yogyakarta: LkiS, 1996).

${ }^{12}$ Lasiyo, "Ajaran Konfucianisme, Tinjauan Sejarah dan Filsafat", dalam Lasiyo, dkk., Pergulatan dalam Menacari Jati Diri, (Yogyakarta: Interfidei, 1995), h. 20. 
Cina berikutnya, khususnya para pemikir neo-Konfucian dari dinasti Sung (960-1279 M), yang secara dangkal menolak pengaruh-pengaruh Taois dan Budhis, tetapi dalam kenyataannya meminjam dan mensintesakan banyak hal dari kedua tradisi itu. ${ }^{13}$

Oleh karena itu, tidak heran banyak pakar mengatakan bahwa Konfuciusme, Taoisme, dan Budhisme bukanlah suatu agama, melainkan sebuah paham atau aliran yang banyak mengajarkan ajaran moral. Sebab kajian suatu agama tidak bisa dipisahkan dari siapa Nabi atau pendirinya, kitab sucinya, dan konsepnya tentang Tuhan. Sementara dalam konsep teologi Cina, baik itu Konficius, Taoisme, dan Budhisme tidak begitu jelas.

\section{Konsep tentang Humanisme}

Manusia adalah obyek yang paling tinggi dalam penciptaan, bukan karena dia sendiri dapat mengusahakan keselamatan, tetapi karena ia mampu membangun suatu kebudayaan dan peradaban. Karena penghargaan yang mendalam terhadap manusia, kebudayaan, dan peradabannya, bangsa Cina dapat mengembangkan suatu pemikiran sosial dan politik yang baik dan pandangan etis yang inspiratif. Gagasan tentang demokrasi yang ideal sebenarnya bermula dari Konfucius. Bahkan ada sementara ahli mengatakan bahwa Revolusi Perancis sebenarnya terpengaruh oleh gagasan ini, entah langsung atau tidak. Pemahaman-pemahaman tentang semantik juga berasal dari ratusan sekolah-sekolah Cina yang mempelajari namanama. Bangsa Cinalah sebenarnya pertama kali menemukan kertas, seni mencetak, serbuk mesiu, tanpa merasa perlu menyusun metodologi sistematis ilmiah, justru karena bentuk penghargaan bangsa Cina terhadap manusia. ${ }^{14}$

Humanisme di Eropa sudah mengalami kajian yang mendalam dan mendetail sejak Auguste Comte yang telah mempeloporinya dengan istilah agama yang humanistik. Manusia merupakan makhluk Tuhan yang lemah dengan keterbatasannya, dan itu merupakan ketidaksempurnaan dari sifat humanisme itu sendiri.

${ }^{13}$ Robert C. Solomon dan Kathleen M. Higgins, Sejarah Filsafat, terj. Saut Pasaribu, (Yogyakarta: Bentang Budaya, 2002), h. 192.

${ }^{14}$ Majalah Filsafat Driyarkara, Tahun XXVI, No. 3, Tahun 2001 
Ciri humanisme dari pemikiran filsafat Cina terwakili melalui Confucius yang mempunyai ajaran hsiao, kebaktian. Yaitu bakti seorang pada leluhur dan orang tuanya. Penyembahan leluhur berhubungan dengan hsiao, sebab utuk melakukan penyembahan, haruslah melalui seorang anak laki-laki dalam keluarga. ${ }^{15}$ Pemujaan yang sunguh-sunguh pada leluhur pada masa itu memberi corak tertentu dalam masyarakat. Maka dengan demikian berkembanglah sistem yang paling kompleks dan teratur. Sebagian besar ajaran confucius ini ditujukan untuk membenarkan secara rasional ataupun menyatakan secara teoritis sistem kekeluargaan ini sebagai landasan humanisme dalam filsafat Cina. Adapun yang dijadikan sistem sosial di Cina adalah sistem keluarga. Ada lima hubungan sosial tradisional yang ada di Cina, yaitu: hubungan antara raja dan hamba, ayah dan anak, kakak dan adik, suami dan istri, teman dan teman. ${ }^{16}$

Hormat kepada orang tua selain merupakan salah satu karakteristik pemikiran filsafat Cina, juga kejiwaan orang Cina yang memiliki peranan serta pengaruh dalam berbagai aspek kehidupan baik pribadi, keluarga, masyarakat, bangsa, maupun negara. Hormat kepada orang tua (filial piety) mengajarkan bahwa, kedurhakaan seorang anak kepada orang tuanya adalah tindakan yang amat tercela, demikin pula orang tua yang tidak berlaku baik dan kasih sayang terhadap anaknya, kakak terhadap adiknya, adik terhadap kakaknya, istri terhadap suami dan suami terhadap istri. Filial Piety mendasari konsep etika dalam pemikiran filsafat Cina, khususnya dalam hubungan kekeluargaan, yang kemudian dikembangkan melalui konsep loyality melandasi hubungan kemasyarakatan maupun kebangsaan dalam arti luas. Sifat yang kurang begitu menonjol dalam pemikiran dalam filsafat Barat ${ }^{17}$

Dengan demikian, dapat dibedakan humanisme yang terdapat dalam filsafat Cina berbeda dengan humanisme yang dipahami di Barat yang hanya menekankan pada satu aspek saja, manusia. Kalau dalam humanisme Cina ada hubungan yang erat antara manusia dengan Thien (sorga) sebagai suatu kesatuan yang tak terpisahkan.

\footnotetext{
${ }^{15}$ Nio Joe Lan, Tiongkok......h. 46.

${ }^{16}$ Fung Yu-Lan, A Short History of Chinese Philosophy, (New York: The McMillan Company, 1948), h. 29.

${ }^{17}$ Lihat Lasiyo, Pemikiran Filsafat Timur dan Barat, dalam Jurnal Filsafat, Fakultas Filsafat Universitas Gajah Mada Yogyakarta, No. 27 Th. 1997, h. 4.
} 
Meng Tze atau Mencius (372 - 289 S.M.) adalah murid dari Konfucius yang terbesar. Ia meneruskan dan mengembangkan ajaran gurunya tersebut. Terutama ia mengajarkan demokrasi, hingga saat ini ungkapannyaa masih terkenal" Min Wei Kuei" Rakyat adalah yang utama. Mencius pernah mengatakan bahwa dinasti Chou telah kehilangan kerajaannya, karena kehilangan rakyat, kehilangan kepercayaan rakyat. Untuk itu menurutnya cara memperoleh rakyat adalah dengan mencari kepercayaan rakyat, dan jalan untuk memperolehnya ialah berikan kepada mereka apa yang disukainya. ${ }^{18}$ Rakyat merupakan poin penting dalam suatu negara, tanpa rakyat tidak akan ada kekuasaan, dan kekuasaan itu sendiri hakekatnya adalah untuk kepentingan rakayat. Hal ini jelas sesuai dengan prinsip demokrasi itu sendiri, yaitu dari, untuk, dan oleh rakyat. Namun berbeda dengan konsep demokrasi yang dipahami pada umumnya, pemimpin bagi Mencius bukan atas dasar pilihan rakyat, tetapi adalah putra sorga di dunia (Thien), cuma ia haruslah bisa diterima oleh rakyat karena ia melaksanaakan prinsipprinsip kemanusiaan dan keadilan. ${ }^{19}$ E.R. Hughes sebagaimana dikutip oleh Nio, mengatakan bahwa Mencuis kalau dipandang dari sudut Realis Barat Frame of mind (kerangka berfikirnya) bersifat Idealis, dari sudut kaum idealis ia bersifat Realis. ${ }^{20}$

Bisa dipahamai praktek nilai-nilai kemanusiaan dalam filsafat Cina tidak hanya terkonsentrasi pada keluarga dalam scope kecil, tetapi juga merambah pada urusan yang berkaitan dengan negara, sebagaimana telah dikemukakan oleh Mencuis. Artinya setiap orang mempunyai potensi arif dan bijaksana asalkan ia mau belajar menghargai sifat kemanusiaannya untuk kepentingan bersama.

Sisi lain dari pandangan filsafat Cina yang menonjol adalah tentang humanisme, yaitu masalah keseimbangan. Manusia dalam hidup ini semestinya selalu menjaga keseimbangan, agar ia dapat hidup bahagia. Sifat secara rinci diajarkan dalam Yin dan Yang, yang menyatakan bahwa di alam semesta pada dasarnya terdapat dua prinsip, yaitu prinsip positif (Yang) dan negatif (Yin). Secara sepintas nampak bahwa keduanya merupakan

\footnotetext{
${ }^{18}$ Nio Joe Lan, Tiongkok..........h. 48.

${ }^{19}$ Paul Chau, Chinese Kinship, (London: Paul Kegan International Ltd., 1983), h. 74.

${ }^{20}$ Ibid.
} 
dua hal yang berbeda, namun sebaliknya keduanya saling melengkapi. Walau nampak berlawanan, tetapi keduanya sebagai penyeimbang. ${ }^{21}$

Kalau Konfuciusme tampak memusatkan perhatiannya pada manusia yang hidup di tengah-tengah masyarakat, maka Taoisme lebih menekankan manusia sebagai manusia itu sendiri. Bahkan jika Konfuciusme dipandang sebagai yang dominan di Cina, arus pemikiran filsafat Cina jelas lebih menekankan ke arah luar diri ekslusif manusia.

Hal ini tampak pada pandangan Konfucianism yang menyatakan bahwa dalam pergaulan, tindakan seseorang selalu berhubungan dengan orang lain. Hubungan ini dapat dikelompokkan menjadi lima pertalian pokok, yaitu, ayah dan anak, saudara dan saudara, suami dan istri, sahabat dan sahabat, serta yang berkuasa dan yang dikuasai. Dalam hubungan ini, setiap pihak berkelakuan sesuai dengan kedudukannya. Ayah mencintai anak, anak menghormati, kakak berbaik hati, adik menjunjung, suami tulus, istri patuh. Sahabat lebih tua peka, sahabat muda khidmat. Yang berkuasa murah hati, yang dikuasai setia. Tiga dari lima pertalian itu merupakan hubungan keluarga, karena keluarga dapat dianggap sebagai dasar masyarakat. Dalam lembaga sosial inilah, manusia dididik diajar kebaikan, dan dibentuk tabiatnya. ${ }^{22}$

\section{Tinjauan Kritis Analitis}

Dalam pemikiran filsafat Cina yang di dominasi oleh Taoisme, Confucianisme, dan Budhis tampak bahwa konsep tentang ketuhanan memang tidak menjadi hal yang urgen dalam kajian teologis mereka. Hal ini barangkali disebabkan oleh fokus mereka pada penanaman nilai ethic moral yang menjadi way of live mereka dalam tradisi yang sangat kuat mereka pegang. Namun penulis melihat ada kesamaan tentang Kosmologi Cina dengan kosmologi Islam dalam beberapa hal, karena ia bertumpu pada konsep polaritas prinsip-prinsip aktif dan reseptif. Misalnya, Tuhan (Allah) menurut para sufi lebih diidentikkan dengan sifat-sifat keindahan (jamấ), seperti Maha Pengampun, Maha Pengasih, Maha Penyayang, dan

\footnotetext{
${ }^{21}$ Lasiyo, Pemikiran Filsafat......., h. 4.

${ }^{22}$ Rudi Setiadi, "Benarkah Mereka Maju Karena Konfusinisme?", dalam Pikiran Rakyat, edisi 8 April 2003.
} 
lain sebagainya atau Yin dalam tradisi Cinanya. Sedangkan dalam perspektif teologi lebih diidentikkan dengan keagungan (jalâh), seperti Maha Perkasa, Maha Kuasa, Maha Besar, dan lainnya atau yang disebut dengan Yang. Kedua perspektif ini membentuk dua kutub dalam pemikiran Islam. Perlu ada keseimbangan yang sangat bagus dan baik antar kedua kutub tersebut. Teologi negatif maupun positif diperlukan untuk melahirkan pemahaman yang benar tentang realitas Ilahi.

Selain itu, aliran konfucianism tidak sepenuhnya sepakat tentang apakah manusia pada dasarnya baik. Hsun tzu (298-230 SM) bersikeras tentang sebaliknya. Dalam pandangannya, manusia pada dasarnya jahat, dengan kecenderungan bawaan untuk mengejar tujuan dan kesenangan pribadi. Akan tetapi, untunglah manusia juga cerdas dan dengan kecerdasannya dapat mengolah kebaikan yang ada dalam dirinya. Sesuai dengan doktrin Konfucianism, Hsun tzu menekankan pentingnya ritual dan perilaku yang pantas terhadap orang-orang di sekeliling kita, khususnya kepada anggota keluarga. Moralitas tidak didasarkan pada alam, tetapi sebaliknya, moralitas adalah temuan inteligensi manusia, dibangun untuk menjamin kerjasama sosial untuk menghadapi keinginan-keinginan kita yang lebih alamiah, lebih mementingkan diri sendiri. ${ }^{23}$

Dalam konsep humanisme pemikiran filsafat Cina mempunyai corak tersendiri bila dibandingkan dengan humanisme yang dianut di Barat dan pada umumnya. Kalau di Barat manusia yang dianggap makhluk yang tidak sempurna dan mempunyai keterbatasan yang merupakan ciri khasnya dan hanya berorientasi pada sifat-sifat kemanusiaan semata. Sedangkan humanisme dalam tradisi Cina tidak ada pengingkaran pada Yang Maha Agung yang menunjukkan adanya unifikasi dengan antara manusia sebagai Makhluk dan Tuhan sebagai Khalik. Barangkali pemikiran filsafat Cina yang dalam hal ini wakili oleh Confucianisme mempunyai warna islami, yaitu adanya Hablum min Allâb wa bablum min an-Nâs.

\section{Penutup}

Dalam pemikiran filsafat Cina yang di dominasi oleh Taoisme, Confucianisme, dan Budhis, konsep tentang ketuhanan memang tidak

${ }^{23}$ Robert C. Solomon dan Kathleen M. Higgins, h. 190. 
menjadi hal yang urgen dalam kajian teologis mereka. Hal ini barangkali disebabkan oleh fokus mereka pada penanaman nilai ethic moral yang menjadi way of live mereka dalam tradisi yang sangat kuat mereka pegang. Dalam konsep humanisme pemikiran filsafat Cina mempunyai corak tersendiri bila dibandingkan dengan humanisme yang dianut di Barat dan pada umumnya []

\section{DAFTAR PUSTAKA}

Al-Qur'an al-Karim Departemen Agama RI

David Trueblood, (1990). Filsafat Agama, terj. H.M. Rasyidi, Jakarta: Bulan Bintang.

Elizabeth Seeger, (1951). Sejarah Tiongkok Selayang Pandang, terj. Ong Pok Kiat dan Sudarno, Jakarta: J.B. Wolters-Groningen.

Fung Yu-Lan, (1948). A Short History of Chinese Philosophy, New York: The McMillan Company.

H.G. Creel, (1990). Alam Pikiran Cina, Sejak Konfucius sampai Mao Zedong, terj. Soejono Sumargono, Yogyakarta: Tiara Wacana.

Lasiyo, (1995). "Ajaran Konfucianisme, Tinjauan Sejarah dan Filsafat", dalam Lasiyo, dkk., Pergulatan dalam Menacari Jati Diri, Yogyakarta: Interfidei.

_ (1997). "Pemikiran Filsafat Timur dan Barat", dalam Jurnal Filsafat, Fakultas Filsafat Universitas Gajah Mada Yogyakarta, No. 27.

Majalah Filsafat Driyarkara, Tahun XXVI, No. 3, Tahun 2001

Nio Joe Lan, (1952). Tiongkok Sepanjang Abad, Jakarta: Balai Pustaka.

Paul Chau, (1983). Chinese Kinship, London: Paul Kegan International Ltd.

Robert C. Solomon dan Kathleen M. Higgins, (2002). Sejarah Filsafat, terj. Saut Pasaribu, Yogyakarta: Bentang Budaya.

Rudi Setiadi, (2003). "Benarkah Mereka Maju Karena Konfusinisme?”, dalam Pikiran Rakyat, edisi 8 April. 